Article

\title{
Biological Activities and Proteomic Profile of the Venom of Vipera ursinii ssp., a very Rare Karst Viper from Croatia
}

\author{
Maja Lang Balija ${ }^{1,+}$, Adrijana Leonardi $^{2,+}{ }^{\mathbb{D}}$, Marija Brgles ${ }^{1}$, Dora Sviben ${ }^{1}$, Tihana Kurtović ${ }^{1} \mathbb{D}$, \\ Beata Halassy ${ }^{1, *(\mathbb{D})}$ and Igor Križaj ${ }^{2, * \mathbb{D}}$ \\ 1 University of Zagreb, Centre for Research and Knowledge Transfer in Biotechnology, Rockefellerova 10, \\ HR-10 000 Zagreb, Croatia; maja.langbalija@gmail.com (M.L.B.); mbrgles@gmail.com (M.B.); \\ dora.sviben@gmail.com (D.S.); tihana.kurtovic@unizg.hr (T.K.) \\ 2 Jožef Stefan Institute, Department of Molecular and Biomedical Sciences, Jamova cesta 39, SI-1000 Ljubljana, \\ Slovenia; adrijana.leonardi@ijs.si \\ * $\quad$ Correspondence: bhalassy@unizg.hr (B.H.); igor.krizaj@ijs.si (I.K.) \\ + These authors contributed equally to this work.
}

Received: 6 February 2020; Accepted: 12 March 2020; Published: 16 March 2020

check for updates

\begin{abstract}
The karst viper (Vipera ursinii ssp.) favours high-mountain dry grasslands in southern and south-eastern Croatia. It is medically less important than other Vipera species, because of its remote habitat and the very small amount of venom that it injects by its relatively short fangs. The scientific literature on Vipera ursinii deals mostly with the morphology, ecology and distribution range of this snake, due to the species' conservation issues, while the toxinological aspects of its venom have not so far been investigated. Here we report on the composition and biological activity of the Vipera ursinii ssp. venom. Using a proteomics approach, we have identified 25 proteins in the venom that belong to seven protein families: snake venom metalloproteinase, serine protease, secreted phospholipase $A_{2}$, cysteine-rich secretory protein, snake C-type lectin-like protein, serine protease inhibitor and nerve growth factor. The Vipera ursinii ssp. venom was found to be distinctively insecticidal. Its lethal toxicity towards crickets was more than five times greater than that of Vipera ammodytes ammodytes venom, while the opposite held in mice. Interestingly, the mode of dying after injecting a mouse with Vipera ursinii ssp. venom may suggest the presence of a neurotoxic component. Neurotoxic effects of European vipers have so far been ascribed exclusively to ammodytoxins and ammodytoxin-like basic secreted phospholipases $\mathrm{A}_{2}$. Structural and immunological analyses of the Vipera ursinii ssp. venom, however, confirmed that ammodytoxin-like proteins are not present in this venom.
\end{abstract}

Keywords: snake venom; Vipera ursinii ssp.; karst viper; toxicity; venomics; insecticide

Key Contribution: We have analysed the proteomic and toxinological profiles of the venom of Vipera ursinii ssp., an endangered entomophagous viper. The proven high potential to kill insects implies the existence of insect-specific toxins in this venom, potentially interesting as bioinsecticides.

\section{Introduction}

Orsini's viper, Vipera ursinii, is one of the most endangered snake species in Europe. Currently, four subspecies are officially recognized [1], but an additional one may be introduced based on a recent mitochondrial DNA analysis [2]. Three of them, V.u. ursinii, V. ursinii ssp. and V. u. macrops, prefer living at higher altitudes in mountain grasslands (karst vipers), while $V . u$. rakonsiensis and $V . u$. moldavica prefer lowlands (meadow vipers). The distribution area of $V$. ursinii is highly fragmented and covers south-western France, central Italy, Hungary, Romania as well as western and eastern parts 
of the Dinaric Mountains. Due to the threat of extinction, the Council of Europe adopted, in 2005, the V. ursinii protection plan [3].

V. ursinii ssp. (Figure 1) is a poorly described, novel subspecies that lives in the north-western part of the Dinarides (Croatia, Bosnia and Herzegovina). It is genetically separated from the other karst vipers that inhabit the Dinaric Mountains all the way to Albania, and is more like the West European subspecies [1,4]. The Croatian V. ursinii ssp. is a highly endangered viper that is found in five isolated localities: in southern Velebit, Poštak, Dinara, Troglav and the Kamešnica mountains, at altitudes

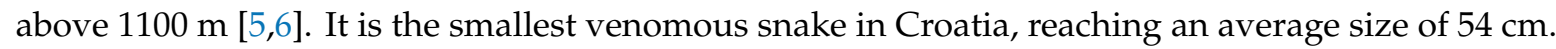
Typically, its head is clearly separated from its neck and the body is short and smooth. The grey or brownish ground colour is usually lighter dorsally. In most cases, the animal is also characterized by a dark zigzag pattern along its back. The snake is entomophagous, i.e., its typical diet comprises insects (grasshoppers and crickets) [7]. People rarely encounter this snake, so accidents are very scarce. In addition, the snake has very short fangs $(2-3 \mathrm{~mm}$ ) through which it can inject only minute amounts of venom (1-4 mg). Accordingly, the symptoms reported in patients envenomed by the $V$. ursinii venom have been very mild and local, and were resolved spontaneously without medical intervention [8].

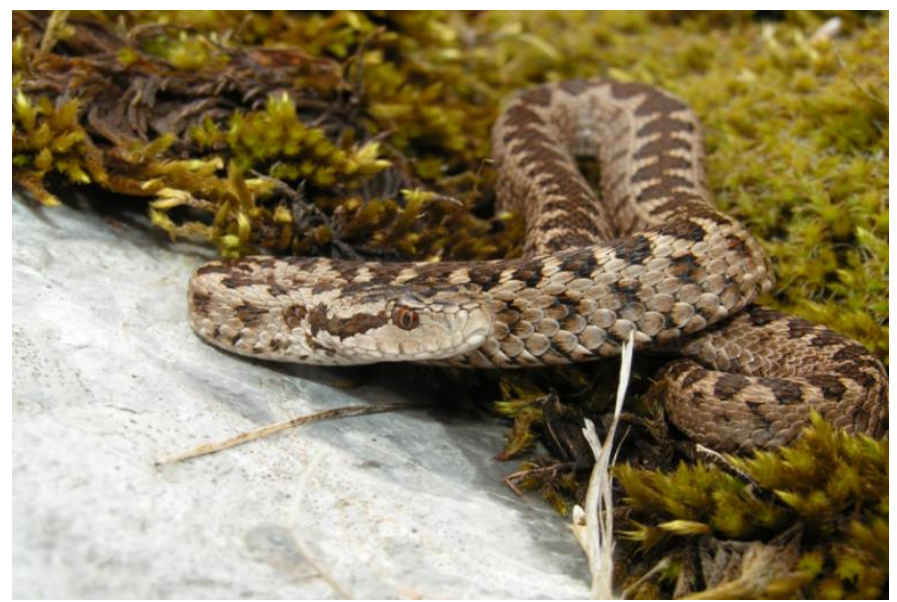

Figure 1. The karst viper (V. ursinii ssp.) is a short, light grey or brownish snake characterized by a dark zigzag pattern along its back. This one was photographed in southern Velebit, Croatia (photo by Dušan Jelić, and we got the copyright permission of Dušan Jelić).

The scientific literature on V. ursinii deals mostly with its morphology, ecology and distribution, addressing, in the first place, its preservation problems $[1,3,9,10]$, while its venom composition and toxic activities have been only poorly investigated. Regarding the latter, the venom of $V$. ursinii was reported, in mice, to be haemorrhagic but not myotoxic [11]. The mRNA transcripts of two secreted phospholipases $\mathrm{A}_{2}\left(\mathrm{sPLA}_{2} \mathrm{~s}\right)$, ammodytin $\mathrm{I}_{1}\left(\mathrm{AtnI}_{1}\right)$ and ammodytin $\mathrm{I}_{2}\left(\mathrm{AtnI}_{2}\right)$, were identified in the $V$. ursinii venom glands [12].

To obtain an insight into the functioning at the molecular level of the venom of this rare and ecologically very distinctive snake, we report here a toxinological description of the venom along with its comprehensive proteomic analysis. This opened the way to unravelling a unique insecticidal activity, leading potentially to new pesticides.

\section{Results}

\subsection{Toxinological Characterisation of V. ursinii ssp. Venom}

The lethal toxicity of $V$. ursinii ssp. venom was determined in mice and crickets. V. ursinii ssp. venom was less toxic than $V$. $a$. ammodytes venom in mice-its average $\mathrm{LD}_{50}$ was more than 4 times higher than that of $V$. a. ammodytes venom (Table 1). Clinical pictures of mice dying from V. ursinii ssp. or $V$. a. ammodytes venom were similar. After i.v. application of venom, animals rapidly showed signs 
of anxiety and severe dyspnoea, followed by convulsions and ataxia with spasms. Finally, they died. Such symptoms are characteristic of neurotoxins or stroke. The two venoms, however, differ distinctly in that $V$. ursinii ssp. venom induced sudden and sporadic, dose-unrelated deaths when injected in experimental animals, while $V$. a. ammodytes venom did not.

Table 1. Lethal toxicity and haemorrhagic potency of the Croatian $V$. ursinii ssp. (VuCro) and V.a. ammodytes $(V a a)$ venoms. Results are given as the mean of $n$ determinations \pm SEM. MHD stands for minimal haemorrhagic dose.

\begin{tabular}{ccc}
\hline & $\boldsymbol{V u}$ Cro Venom & Vaa Venom \\
\hline Lethal Toxicity & & \\
\hline LD $_{50}$ in mice $(\mu \mathrm{g})$ & $37.0 \pm 0.1(n=2)$ & $4.4-13.7^{*}$ \\
L** Mass-normalized LD 50 in mice $(\mu \mathrm{g} / \mathrm{g})$ & 1.94 & 0.47 \\
LD $_{50}$ in crickets $(\mu \mathrm{g})$ & $7.1 \pm 0.4(n=2)$ & $38.7 \pm 3.3(n=2)$ \\
** Mass-normalized LD $D_{50}$ in crickets $(\mu \mathrm{g} / \mathrm{g})$ & 9.8 & 53.4 \\
\hline Haemorrhagic Activity & & $21.6-42.8^{*}$ \\
\hline MHD in rats $(\mu \mathrm{g})$ & $34.1 \pm 4.8(n=4)$ &
\end{tabular}

${ }^{*}$ Depending on geographical location (determined by Halassy et al. $\left.[13,14]\right) .{ }^{* *}$ Mass-normalized LD $_{50}$ values were calculated as the average $\mathrm{LD}_{50}$ (in $\mu \mathrm{g}$ )/average body mass of experimental animal (in $\mathrm{g}$ ) ( $0.725 \mathrm{~g}$ for crickets; $19 \mathrm{~g}$ for mice).

Both venoms were also lethally toxic for crickets. In contrast to the results in mice, V. ursinii ssp. venom displayed higher toxicity in crickets than $V$. a. ammodytes venom. The average $\mathrm{LD}_{50}$ of the first was more than 5-fold lower than that of the latter (Table 1). Interestingly, for both types of animals, the $\mathrm{LD}_{50}$ values are in the same $\mu \mathrm{g}$ range. The species selectivity of a particular venom is clear-comparing mass-normalized $\mathrm{LD}_{50} \mathrm{~s}, V$. a. ammodytes venom was almost 114 -fold more lethal for mice than for crickets, while $V$. ursinii ssp. venom was only 5 -fold (Table 1 ).

The haemorrhagic activities of the two venoms in rats were similar (Table 1).

\subsection{Immunological Cross-Reactivity between V. ursinii ssp. and V. a. ammodytes Venoms}

Rabbit antisera against the whole $V$. a. ammodytes venom (anti-Vaa) and its various components, the pool of $V$. a. ammodytes haemorrhagins (anti-H), V.a. ammodytes neurotoxic sPLA 2 Atx (anti-Atx) and $V$. a. ammodytes non-toxic sPLA $\mathrm{AtnI}_{2}\left(\operatorname{anti}-\mathrm{AtnI}_{2}\right)$ were used to probe cross-reactivity between the $V$. ursinii ssp. venom components, using WB and ELISA assays. Anti-Vaa, anti-H and anti-AtnI 2 antibodies proved to be paraspecific in ELISA tests. On the other hand, anti-Atx antibodies did not recognize the $V$. ursinii ssp. venom-coated ELISA plate at all (Figure 2). ELISA results were confirmed by WB analysis. As shown in Figure 3, Atx-like sPLA ${ }_{2}$ s were not detected using Atx-specific antibodies in $V$. ursinii ssp. venom. 
A

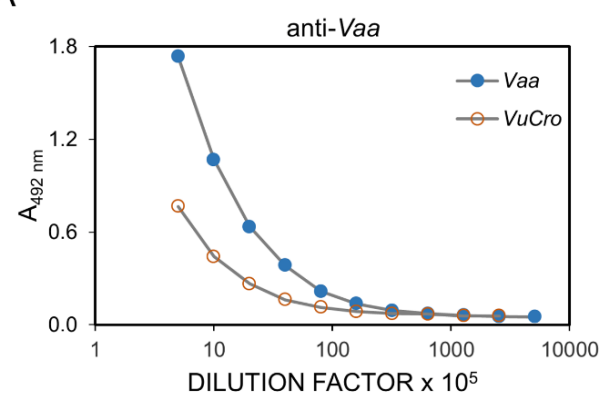

C

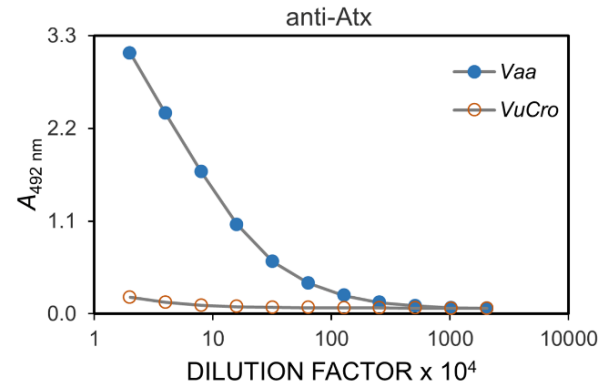

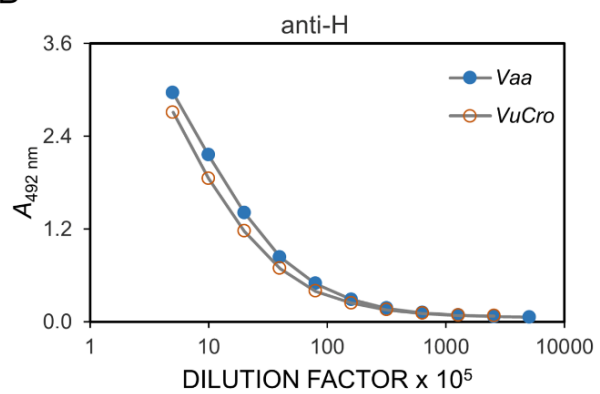

D

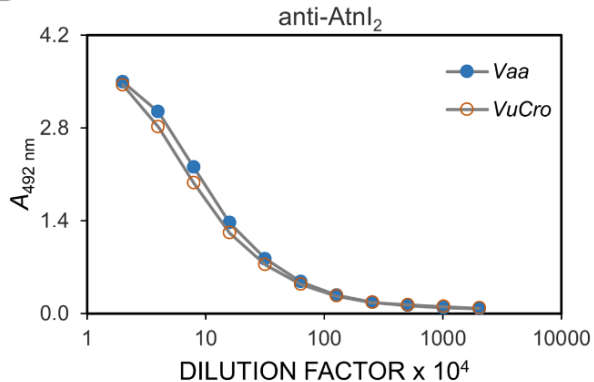

Figure 2. Antigen similarity of $V$. ursinii ssp. and $V$. a. ammodytes venoms by ELISA. The venoms of the Croatian $V$. ursinii ssp. ( $V u C$ ro) and $V$. a. ammodytes (Vaa) were compared by ELISA assay using rabbit antibodies raised against the whole $V$. $a$. ammodytes venom (anti-Vaa) (A), the pool of $V$. a. ammodytes haemorrhagins (anti-H) (B), V. a. ammodytes neurotoxic sPLA 2 Atx (anti-Atx) (C) and V. a. ammodytes non-toxic sPLA AtnI $_{2}$ (anti-AtnI $)_{2}$ (D). All sera, except anti-Atx, recognized components of the $V$. ursinii ssp. venom, suggesting that neurotoxic Atx is absent in this venom. Antibody binding was detected by incubation with HRP-anti-rabbit IgG and the subsequent OPD-based colour reaction.

A

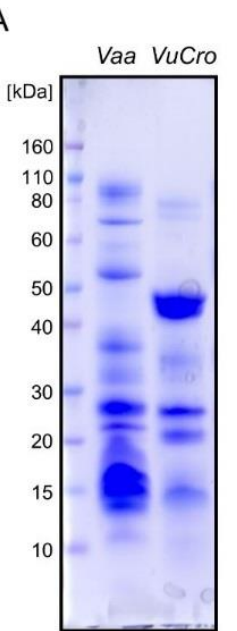

B Vaa VuCro Vaa VuCro

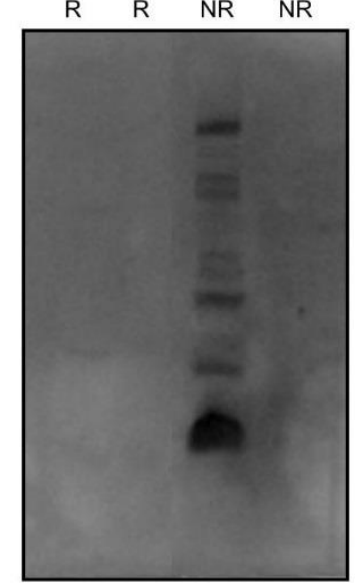

Figure 3. WB analysis of V. ursinii ssp. and V. a. ammodytes venoms using anti-Atx serum. Crude venoms of the Croatian $V$. ursinii ssp. $(V u C r o)$ and $V$. a. ammodytes (Vaa) $(40 \mu \mathrm{g} / \mathrm{lane})$ were analysed on $4-12 \%$ SDS-PAGE gel under non-reducing (A) and reducing conditions. Proteins in gels were either stained with CBB R250 (A) or electro-transferred in tank onto the PVDF membrane and immuno-stained using anti-Atx serum and an ECL detection system (B). On Western blots, signals appeared only in the case of the $V$. a. ammodytes venom sample under non-reducing conditions, thus confirming the absence of Atx-like proteins in the $V$. ursinii ssp. venom. 


\subsection{Proteomics of V. ursinii ssp. Venom and Its Comparison with V. a. ammodytes Venom}

\subsubsection{Proteome of V. ursinii ssp. Venom}

To analyse the $V$. ursinii ssp. venom proteome, the crude venom collected from the wild snakes was separated by 1-DE in the molecular mass range 10 to $80 \mathrm{kDa}$ (Figure $4 \mathrm{~A}$ ), and by 2-DE in the isoelectric point (pI) range of 3 to 10 and a molecular mass range of 3.5 to $110 \mathrm{kDa}$ (Figure $4 \mathrm{~B}$ ). $V$. ursinii ssp. venom was resolved into seven and eight distinct bands on non-reducing and reducing 1-DE, respectively.

A

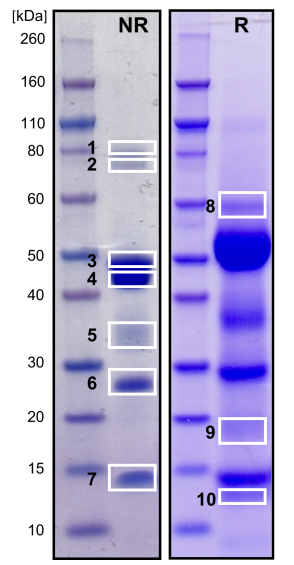

B

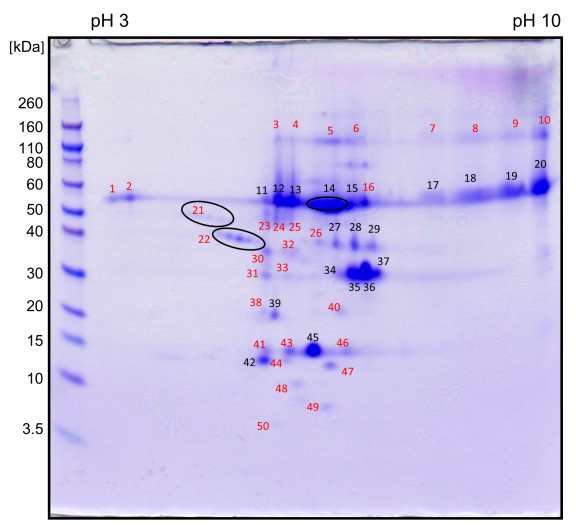

C

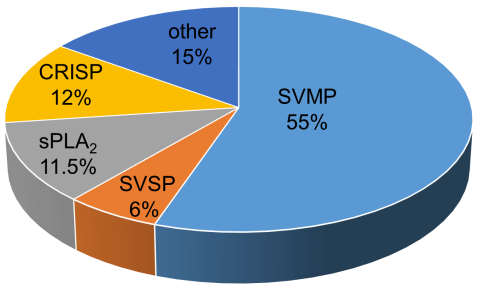

Figure 4. Profiling of the protein composition of $V$. ursinii ssp. venom of snakes living in the wild. (A) The $V$. ursinii ssp. venom (40 $\mu \mathrm{g} /$ well) was analysed by SDS-PAGE under non-reducing (NR) and reducing (R) conditions on $4-12 \%$ Bis-Tris gel. (B) $250 \mu \mathrm{g}$ of the venom was separated in two dimensions, using a $7 \mathrm{~cm}$ IPG strip, $\mathrm{pH} 3-10$, in the first, and $4-12 \%$ Bis-Tris gel in the second dimension. Proteins in the gels were stained with CBB R250. The indicated bands (white frames) and spots (red numbers) were excised and trypsinized. The obtained peptides were extracted from the gel and analysed by ESI-MS/MS. Black numbers on the 2-DE gel denote proteins that were identified by ESI-MS/MS of 1-DE bands (A). (C) Relative abundance (\% of the total venom protein content) of major protein families in $V$. ursinii ssp. venom was estimated from intensities of the 2-DE spots in which they were detected. SVMP, snake venom metalloproteinase; CRISP, Cys-rich secretory protein; $\mathrm{SPLA}_{2}$, secreted phospholipase $\mathrm{A}_{2}$; SVSP, snake venom serine protease.

More than 50 protein spots were observed on the 2-DE gel. We assumed that proteins from the most intense bands on the 1-DE gel were those appearing as the major spots in the 2-DE gel at the same molecular masses, e.g., at $\sim 50, \sim 35, \sim 30$ and $\sim 15 \mathrm{kDa}$. Proteins from the 1-DE Bands 3 and 4 thus constituted mostly 2-DE Spots 11-20. The major protein from Band 5 was located in 2-DE Spots 27 to 29, the one from Band 6 in 2-DE Spots 34 to 37, and proteins from Band 7 mostly in 2-DE Spots 42 and 45. For the MS analysis, dominant protein bands were thus excised from the non-reduced 1-DE gel (7 bands labelled on the gel in Figure 4A). Less abundant protein bands were excised from the reduced 1-DE gel ( 3 bands labelled 8 to 10 on the gel in Figure $4 \mathrm{~A}$ ) and picked from the 2-DE gel (31 spots designated by red numbers in Figure 4B).

Again, we assumed that the main protein of 1-DE Band 9 at $\sim 18 \mathrm{kDa}$ is the same as the protein in 2-DE Spot 39, the most intense spot at the same molecular mass. The proteins were trypsinized in-gel and the resulting peptides extracted and analysed by LC-ESI-MS/MS. Altogether, in selected bands and spots, 25 proteins were identified. They can be grouped into seven protein families: snake venom metalloproteinase (SVMP), snake venom serine protease (SVSP), sPLA 2 , cysteine-rich secretory protein (CRISP), snake C-type lectin-like protein (snaclec), Kunitz-type serine protease inhibitor (KSPI) and venom nerve growth factor (VNGF) family (Table S1). No proteins could be identified in Spots 4, 6, 8, 9, 40, 49 and 50, due either to too low amounts of material or to the lack of similar/identical 
sequences in the protein database used to search the MS spectra. The most abundant were proteins of $\sim 50 \mathrm{kDa}$ belonging to the SVMPs that constituted 1-DE Bands 1 to 4 and 8 (corresponding to 2-DE Spots 11 to 20), and 2-DE Spots 1 to 5, 10 and 23 to 25 . The second most abundant were CRISPs, which were identified as the major components of 1-DE Band 6 with apparent molecular masses of $\sim 27 \mathrm{kDa}$ (corresponding to 2-DE Spots 34 to 37). CRISP was also detected as a minor constituent of the 1-DE bands at higher apparent molecular masses of $43 \mathrm{kDa}$ (Band 4) and $35 \mathrm{kDa}$ (Band 5), as well as $50 \mathrm{kDa}$ (2-DE Spot 16). sPLA 2 s were identified in the 1-DE Band 7 and 2-DE Spots 41 to 47, while SVSPs were found mostly in 1-DE Band 5 (corresponding to 2-DE Spots 27 to 29), and in 2-DE Spots 21, 22 and 30. Two KSPIs were identified in 1-DE Band 10, one as a homologue of chymotrypsin inhibitor (0909196A) from V.a. ammodytes and the other as a trypsin inhibitor Vur-KIn (P0DKL8) from the closely related snake $V$. renardi. Relative abundances (expressed in \% of the total venom protein) of major protein families in the $V$. ursinii ssp. venom were estimated from the 2-DE spot intensities. As evident from Figure 4C, SVMPs are the most abundant proteins in the $V$. ursinii ssp. venom, followed by CRISPs, $\mathrm{sPLA}_{2} \mathrm{~s}$ and SVSPs.

For conservation and research purposes, some $V$. ursinii ssp. specimens are kept in captivity, where they experience a food regime different from that in the wild. Namely, captive animals were fed on mice, while, in their natural habitat, they mostly eat insects. In order to examine how different diets influence the venom composition, venoms collected from the snakes in captivity ( VuCro-c) and those obtained from wild animals ( $V u$ Cro) were analysed comparatively by 2-DE (Figure 5A,B). Differences were observed mainly in the acidic part of the 2-DE gels where, in the case of the $V u$ Cro-c venom, certain spots appeared more intense than those in $V u C$ ro venom. In addition, in this area, several additional spots are present in the case of $V u$ Cro-c venom (red encircled Spots 1 to 7 in Figure 5A). Proteins identified in these spots are listed in Table S2. Spots of the increased intensity in VuCro-c regarding to the $V u$ Cro venom (Figure 5A,B) correspond to the Spots 30, 38, 39, 40 and 42 in Figure 4B. In these spots, proteins belonging to SVSPs, sPLA 2 s, SVMPs, snaclecs, VNGFs and KSPIs were identified (Table $\mathrm{S} 1$ ). Of these, $\mathrm{SPLA}_{2} \mathrm{~s}$ appeared much more highly abundant in the venom of animals in captivity $(V u$ Cro-c) than in the venom of those living in the wild $(V u C r o)$. In Table 2 the proteins are listed whose abundance is distinctively different in $V u$ Cro-c and $V u$ Cro venoms.

A

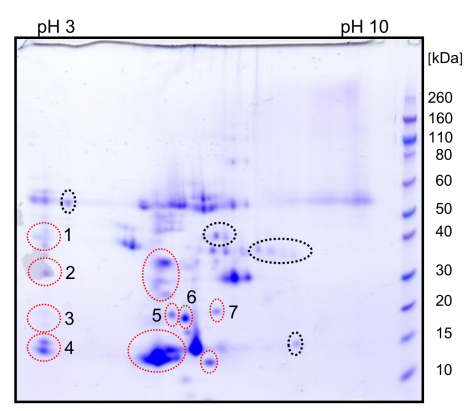

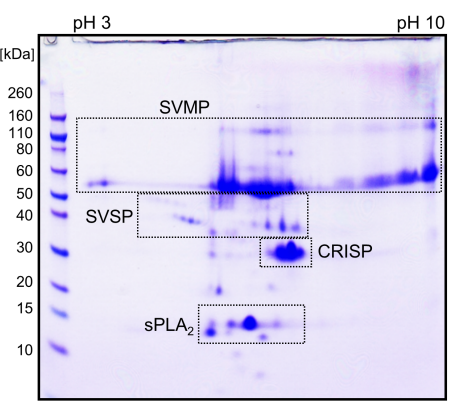

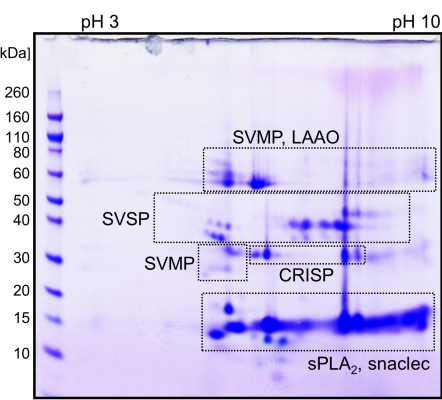

Figure 5. Comparative 2-DE analyses of $V$. ursinii ssp. and $V$. a. ammodytes venoms. The 2-DE profile of the Croatian $V$. ursinii ssp. venom collected from wild snakes $(V u C$ ro) $(\mathbf{B})$ was compared with that of captured $V$. ursinii ssp. snakes $(V u$ Cro-c) $(\mathbf{A})$ or that of the $V$. a. ammodytes venom $(\mathbf{C})$. Distribution of the dominant protein families in the $V$. ursinii ssp. and in the $V$. a. ammodytes venom is framed. Additional (Spots 1-7) or more abundant protein spots in the $V u$ Cro-c venom relative to the $V u$ Cro venom are encircled red. Proteins identified in Spots 1-7 (A) are presented in Table S2. In spots encircled black no proteins were identified. 
Table 2. Proteins with a higher or lower abundance in the venom of the Croatian $V$. ursinii ssp. snakes living in captivity $(V u C r o-c)$ than in the venom of the snakes living in the wild $(V u C r o)$. Abbreviations: AtnI, ammodytin I; CRISP, cysteine-rich secretory protein; KSPI, Kunitz-type serine protease inhibitor; sPLA $_{2}$, secreted phospholipase $\mathrm{A}_{2}$; SVMP, snake venom metalloproteinase; SVSP, snake venom serine protease; VNGF, venom nerve growth factor; Vaa, V. a ammodytes; Vu, V. ursinii.

\begin{tabular}{cc}
\hline Higher Abundance & Protein Family \\
\hline AtnI $_{1}(\mathrm{~B})$ isoform $(V u)$ & $\mathrm{sPLA}_{2}$ \\
Vur-PL2 & $\mathrm{sPLA}_{2}$ \\
AtnI2 (D) isoform $($ Vu $)$ & sPLA $_{2}$ \\
snaclec \\
RVV-X light chain 2 (Daboia siamensis) & SVSP \\
Vaa-SP-3* & SVSP \\
Vaa-SP-4 & SVSP \\
Vaa-SPH-1 $($ Vaa $)$ & VNGF \\
VNGF $($ Vu $)$ & KSPI \\
Vur-KIn $($ V. renardi) & \\
\hline Lower Abundance & \\
\hline Metalloproteinases & SVMP \\
Vaa-CRISP-1 $($ Vaa $)$ & CRISP
\end{tabular}

* Not identified in the $V u$ Cro venom.

\subsubsection{Comparative Analysis of V. ursinii ssp. and V. a. ammodytes Venoms}

Comparative 2-DE analysis of the crude V. ursinii ssp. and V. a. ammodytes venoms exposed large differences in their composition with respect to distribution and intensity of most of the protein spots (Figure 5B,C). The V. ursinii ssp. proteome was compared with the recently published proteome of the $V$. a. ammodytes venom [15]. In general, there are far fewer basic proteins in the V. ursinii ssp. venom than in the $V$. a. ammodytes venom. Further, in the $V$. ursinii ssp. venom, high molecular mass proteins prevail over those with low molecular masses and vice versa in the case of the $V$. a. ammodytes venom. Thus, high molecular mass SVMPs are the major constituents of the $V$. ursinii ssp. venom, while low molecular mass sPLA 2 s and snaclecs dominate in the $V . a$. ammodytes venom. The latter are scarce in the $V$. ursinii ssp. venom, which is also completely devoid of basic sPLA 2 s. SVSPs are found in many spots in both venoms, but in much higher quantities in the V.a. ammodytes venom, where they are also much more diverse regarding their pIs. In contrast, the CRISPs are more abundant in the V. ursinii ssp. than in the $V$. a. ammodytes venom. LAAOs were not detected in the $V$. ursinii ssp. venom. LAAOs are usually the components that colour snake venoms yellow. In accordance with our results, the colour of V. ursinii ssp. venom is only slightly yellow.

\section{Discussion}

V. ursinii ssp. is one of the rarest snakes in Europe. Endangered by extinction, it can be found only in certain mountain regions in Croatia and Bosnia and Herzegovina, at altitudes exceeding $1000 \mathrm{~m}$. Due to the difficulty in encountering this snake in the wild, its venom remained practically unstudied until this work.

Due to its extreme habitat, $V$. ursinii ssp. has a special diet consisting mostly of insects. The adaptation of the snake venom to this prevailing food is clear. Compared to V. $a$. ammodytes, which feeds predominantly on rodents, the venom of V. ursinii ssp. displayed a more than 5-fold higher lethal toxicity in crickets but more than 4 -fold lower toxicity in mice (Table 1). Such an adaptation of venom efficacy to diet has been reported before. For example, the venoms of vipers that are not entomophagous ( $V$. berus and $V$. nikoloski) have a lower toxicity for crickets than those of pronouncedly entomophagous vipers ( $V$. renardi and $V$. lotievi) [7]. In addition, the average mass-normalized $\mathrm{LD}_{50}$ values that we determined in crickets for $V$. ursinii ssp. and $V$. a. ammodytes venoms (Table 1 ) were 
comparable with those reported in [7] for entomophagous and non-entomophagous snakes, 10 and $\sim 30 \mu \mathrm{g} / \mathrm{g}$, respectively.

The lethal toxicities of both $V$. ursinii ssp. and $V$. a. ammodytes venoms were higher in mice than in crickets (Table 1). Higher lethality for mice than for arthropods has also been observed in the case of other viper venoms, e.g., those of the Pelias group of snakes [7] and Echis spp. [16,17]. This points to the fact that, during evolution, rodents have been the principal food of vipers, with other species like insects or scorpions being secondary. Snakes of other families may have developed other food preferences and, correspondingly, venoms with other prey specificities. For example, the venom of a colubrid, the brown tree snake (Boiga irregularis), is more toxic to birds and lizards than to mammals [18]. However, the mass-adjusted $\mathrm{LD}_{50}$ of the V. a. ammodytes venom was more than 100 -fold lower in mice than in crickets, while that of the $V$. ursinii ssp. venom was just 5-fold lower. This shows that $V$. ursinii ssp. adapted to their new living environment in which insects prevail over mice as the available food. The snake, therefore, has been forced to turn from being a mouse-hunting to an insect-hunting animal.

Gel-based proteomic analysis of the venom of the wild $V$. ursinii ssp. species revealed a proteome much simpler than that of the recently published $V$. a. ammodytes venom proteome [15]. Almost two times fewer proteins were identified in the $V$. ursinii ssp. than in the $V$. a. ammodytes venom. While the proteins in the venom of $V$. ursinii ssp. represent seven different protein families, representatives of 16 protein families were found in the venom of $V$. a. ammodytes. Both venoms contain SVMPs, SVSPs, sPLA $_{2}$ s, CRISPs, snaclecs, VNGFs and KSPIs, which are typical of most viperid snake venoms [19,20]. In general, the number of homologues, representatives of the most abundant enzyme families, SVMPs, SVSPs and PLA 2 s, is much lower in the V. ursinii ssp. than in the V. a. ammodytes venom. Furthermore, snaclecs appear only as covalently bound SVMP subunits in the $V$. ursinii ssp. venom. A similar observation was reported in the venomic study of $V$. $b$. berus [21]. In the $V$. a. ammodytes venom, however, snaclecs are also present as an abundant and structurally diversified group of disulphide-linked heterodimeric proteins. Members of the two protein families that are usually present in viperid venoms, LAAOs and disintegrins, were not identified in the $V$. ursinii ssp. venom. So far, of the genus Vipera, only $V$. anatolica, has been reported to be devoid of LAAOs and V. nikolskii of disintegrins [20].

The dominant components of $V$. ursinii ssp. venom are SVMPs, representing 55\% of the total venom proteins (Figure 4C). Among snakes of subfamily Viperinae, to which V. ursinii ssp. belongs, a similar prevalence of SVMPs was also observed in venoms of genera Cerastes and Echis, and $M$. lebetina from Tunisia [20]. SVMPs are structurally and functionally highly diverse zinc-dependent enzymes [22,23]. The V. ursinii ssp. venom displays high haemorrhagic activity. Its MHD in rat is similar to that displayed by the V. a. ammodytes venom (Table 1). The predominance of the P-III class SVMPs in the $V$. ursinii ssp. venom explains its haemorrhagic nature. The high haemorrhagic potential of the P-III SVMPs is based on the presence of non-catalytic domains (disintegrin-like and Cys-rich) in these molecules that mediate their binding to specific substrates in the microvasculature [24]. Haemorrhagic SVMPs namely cause blood microvessel damage by hydrolysing the key proteins in the basement membrane of the capillary wall particularly type IV collagen. This leads to weakening and disruption of the wall due to the hemodynamic pressure. In accordance with the high degree of immunological cross-reactivity of SVMPs from V. ursinii ssp. and V. a. ammodytes venoms (Figure 2), we have identified $V$. ursinii ssp. haemorrhagins, mostly as homologues of those described in the $V$. a. ammodytes venom, VaH3, Vaa-MPIII-1, Vaa-MPIII-3 and Vaa-MPIII-4 (Table S1). Of these, VaH3 has been characterized as one of the main haemorrhagic factors of the $V$. a. ammodytes venom [25]. As an N-glycosylated homodimer, it belongs to the P-IIIc subclass of SVMPs. In vitro, VaH3 also markedly prolonged blood coagulation, due to its fibrinogenolytic activity, but only weakly affected platelet aggregation. Vaa-MPIII-1 and Vaa-MPIII-4 are present in trace amounts in the V. a. ammodytes venom [15]. In contrast, in the $V$. ursinii ssp. venom, these two SVMPs have been identified in several 1-DE bands and 2-DE spots (Figure 4, Table S1). Moreover, Vaa-MPIII-1 appears to be the major SVMP of the V. ursinii ssp. venom. Comparison of the Vaa-MPIII-1 and Vaa-MPIII-4 primary structures 
with those of the other SVMPs whose activities are known, revealed their highest identities $(\sim 75 \%)$ with the haemorrhagic SVMPs from viperid venoms. This suggests that Vaa-MPIII-1 and Vaa-MPIII-4 also possess haemorrhagic activity. Vaa-MPIII-3 is a member of the recently introduced P-IIIe SVMP subclass. That subclass evolved from the classical P-III SVMPs by loss of the MP domain [15], thus consisting of only a complete or a partial disintegrin-like domain and a Cys-rich domain. Interestingly, the V. ursinii ssp. Vaa-MPIII-3 peptides were found in the high molecular mass protein spots (48 to 120 $\mathrm{kDa}$ ), suggesting the existence of a Vaa-MPIII-3-like molecule also containing the MP domain.

The pathologic effect of haemorrhagins can be exacerbated by the action of other venom components that interfere with the processes of blood coagulation and/or platelet aggregation [22]. For example, the extensive and uncontrolled activation or degradation of coagulation factors by SVMPs and SVSPS leads to a consumptive coagulopathy [26]. Potentially having such a role, we found, in the V. ursinii ssp. venom, homologues of two SVMP activators of the coagulation factor X (FX), VLFXA from $M$. lebetina (AAQ17467) and RVV-X from D. russelii. The corresponding proteins in the V. a. ammodytes venom are VAFXAs [27]. All the aforementioned FX activators belong to the P-IIId subclass, in which a dimeric snaclec (light chain) is disulphide-linked to the Cys-rich domain of a P-III SVMP (heavy chain). The snaclec subunit serves to bind the protease to the Gla-domain of FX [28], thus positioning it correctly for effective proteolytic activation of the factor.

We have also identified several members of the SVSP family in the $V$. ursinii ssp. venom that may have pro- and anti-coagulant activities. Those being potentially procoagulant are $V$. ursinii ssp. homologues of RVV-V from the Daboia siamensis venom [29] and Vaa-SP-VX from the V. a. ammodytes venom (Latinović et al., unpublished), which activate FV. In contrast to the SVMP activators of blood coagulation factors, the SVSP activators are usually single-chain molecules with three-dimensional structures that resemble the structure of physiological activators, e.g., the heavy chain of the activated blood coagulation factor X (FXa) and thrombin, though with sequence replacements that confer high substrate specificity and resistance towards the natural inhibitors, the serpins [30]. The most abundant $V$. ursinii ssp. SVSP is a homologue of an anticoagulant V. a. ammodytes protein, Vaa-SPH-1 (KT148824). The latter is an enzymatically inactive SVSP that inhibits the activity of the intrinsic tenase complex by binding to FVIIIa in place of FIXa [31].

Like SVSPs, venom sPLA 2 s can also affect haemostasis in a catalytic activity-independent and/or dependent way [22]. Ammodytoxins (Atx), basic sPLA ${ }_{2} \mathrm{~s}$ from the $V$. a. ammodytes venom, inhibit blood coagulation by binding to FXa, thereby preventing formation of the prothrombinase complex. They have not been detected in the $V$. ursinii ssp. venom. Ammodytins (Atn), acidic sPLA $2 \mathrm{~s}$ from the $V$. a. ammodytes venom, induce anticoagulant and antiplatelet effects by hydrolysing phospholipids [32]. $A_{t n I}$ and $A t_{2}$ are present in the V. ursinii ssp. venom, AtnI $I_{1}$ (CAE47156) being the major isoform. AtnI $I_{1}$ proteins from the $V$. ursinii ssp. and $V$. $a$. aspis (AAN59986) venoms are practically identical (99\% sequence identity). The latter was characterized as being indirectly haemolytic and weakly anticoagulant [33], and the same activities can be expected in the case of the V. ursinii ssp. enzyme. On the other hand, $V$. ursinii ssp. AtnI 2 is probably endowed with a potent haemostatic activity based on 96\% sequence identity with Vur-PL2 (ADG86231) from the closely related Russian snake V. renardi (former $V$. ursinii renardi). Vur-PL2 was namely described as a strongly anticoagulant and platelet aggregation inhibitory enzyme [34]. Although only weakly toxic in mice ( $\mathrm{LD}_{50}=10.7 \mathrm{mg} / \mathrm{kg}$ ), one third of experimental animals died from internal bleeding in various organs at an LD $_{50}$ dose of Vur-PL2.

Although the $V$. ursinii ssp. venom was much less toxic to mice than the V.a. ammodytes venom, the mode of dying of animals after they received a lethal dose of one or other of the venoms was frequently similar, suggesting neurotoxicity as the cause of death. Unusually, the neurotoxic-like effects did not take place in every animal envenomed by the $V$. ursinii ssp. venom, and, when it did take place, they were apparently independent of the received dose of the venom. Such phenomena have never been observed when poisoning mice with the $V$. $a$. ammodytes venom, which suggests different molecular backgrounds of the effects induced by the two venoms. In the case of V. a. ammodytes and related European viper venoms, the neurotoxicity stems from basic sPLA 2 s such as Atx [35]. The latter 
were not found in the $V$. ursinii ssp. venom when using alternative analytical approaches (Figures 2, 3A and 5). A similar situation, i.e., sporadic induction of symptoms considered as neuropathological (e.g., paraesthesia) in spite of the absence of basic $\mathrm{SLLA}_{2} \mathrm{~s}$ in the venom, was also reported for envenomation by venom from $V$. u. ursinii in south-eastern France [12]. If the effects were indeed neurotoxic then they cannot be induced by neurotoxic $\mathrm{SPLA}_{2} \mathrm{~s}$. Sudden and sporadic, dose-unrelated deaths of animals injected with V. ursinii ssp. venom, however, offered also another possible explanation-a stroke, induced by coagulopathic venom components following the i.v. application of the venom.

The non-enzymatic proteins found in the $V$. ursinii ssp. venom are members of the CRISP, VNGF and KSPI protein families, all non-lethal constituents of snake venoms. The CRISP family is represented by homologues of Vaa-CRISP-1 (KT148819) and Dr-CRPK from the D. russelii venom (ACE73567). These two proteins share $90 \%$ sequence identity but neither has a known biological function. Although CRISPs are widespread in snake venoms, knowledge concerning their biological targets and activities is limited. Many so-far characterised CRISPs either modulate the conductivity of various ion channels [36] and induce inflammation [37,38] or have antiprotozoal [39] or antiangiogenic [40] activity.

VNGFs are common components of snake venoms [41] and the $V$. ursinii ssp. venom is not an exception. These molecules are either covalent or non-covalent homodimers expressing nerve growth-promoting activity. Some of them, like the non-covalent homodimer from M. lebetina venom (P25428), are glycoproteins. V. ursini's VNGF (AEH59582) shares 97\% sequence identity with the $M$. lebetina VNGF and has a conserved N-glycosylation site at Asn148. The apparent monomer mass of both $V$. ursinii ssp. and M. lebetina VNGF proteins is $\sim 18 \mathrm{kDa}$ (Figure 3A, Table S1). This suggests that V. ursinii ssp. VNGF is also glycosylated.

Venoms of Viperidae and Elapidae snakes contain 60 amino acid-long Kunitz-type SPIs (KSPIs). We have also identified such molecules in the $V$. ursinii ssp. venom as homologs of VaaChi, a KSPI from the $V$. a. ammodytes venom [42], and Vur-KIn, a KSPI from the V. renardi venom [12]. The structural fold of KSPIs resembles that of the bovine pancreatic trypsin inhibitor [43]. Three KSPIs from the $V$. $a$. ammodytes venom have already been characterised, two as potent inhibitors of trypsin (VaaTi) and as the inhibitor of chymotrypsin (VaaChi) [42]. VaaTi also inhibited plasmin and plasma kallikrein, while VaaChi was shown to form a non-covalent complex with Atx, increasing its toxicity [44]. The activity of Vur-KIn has not yet been determined but it shows the highest sequence identity $(\geq 80 \%)$ with trypsin inhibitors from Viperinae snakes, VaaTi from V. a. ammodytes (P00991), PPTI from Pseudocerastes persicus (COHLB2) and a KSPI from Eristicophis macmahoni (P24541). Further supporting the trypsin inhibitory activity of Vur-KIn is the preservation of its trypsin-interaction site at the N-terminal part of the molecule, with Lys17 at the P1 position. Many trypsin-inhibiting KSPIs interact with coagulation factors, for example thrombin, FXa and FXIa, and therefore express antithrombotic and anticoagulant activities [43].

We observed extensive differences in venom proteomes between $V$. ursinii ssp. snakes living in the wild and those living in captivity (Figure 5; Table 2 and Table S2). This finding was, however, expected given that the animals in captivity had exclusively been fed on mice, as opposed to the primarily insectivorous diet of wild $V$. ursinii ssp. A shift in the venom composition due to a diet change has been described before [45]. In our case, the most prominent difference between the $V u C$ ro and $V u$ Cro-c venom proteomes lay in the content of $s \mathrm{PLA}_{2} \mathrm{~s}$. This finding supports the hypothesis that the acquisition of diverse venom $\mathrm{SPLA}_{2}$ isozymes by accelerated evolution [46] represents a strong selective advantage for diverse physiological functions, including rapid adaptation to available prey through changes in gene expression [47].

\section{Conclusions}

$V$. ursinii ssp. is, ecologically, a very special viper. Its reliance on insect rather than rodent prey is also reflected in the distinctively higher toxicity of its venom for insects than for mice as compared with venom of a closely related, typical mouse-feeding snake, $V$. a. ammodytes. $V$. ursinii ssp. venom is, however, as haemorrhagic to mice as venom from $V$. a. ammodytes. The $V$. ursinii ssp. venom 
proteome is also much less complex than that of $V$. a. ammodytes, containing representatives of only seven different protein families compared to 16 in $V$. a. ammodytes. In addition, most of these families contain fewer protein isoforms in V. ursinii ssp. compared to V. a. ammodytes. SVMPs, which are the most abundant proteins in the $V$. ursinii ssp. venom, are most likely responsible for its haemorrhagic property. The insecticidal activity also suggests the existence of insect-specific toxins in the V. ursinii ssp. venom, which may have potential as bioinsecticides.

\section{Materials and Methods}

\subsection{Reagents and Chemicals}

Bovine serum albumin (BSA), Tween 20 and $o$-phenylenediamine dihydrochloride (OPD) were from Sigma-Aldrich, Saint Louis, MO, USA. Horseradish peroxidase-conjugated goat anti-rabbit IgG (HRP-anti-rabbit IgG) was from Bio-Rad Laboratories, USA. Iodoacetamide (IAA), 1,4-dithio-DL-threitol (DTT), $\alpha$-cyano-4-hydroxycinnamic acid (CHCA), Coomassie Brilliant Blue R250 (CBB R250), and all peptide standards were from Sigma, USA. Chemicals for buffers and solutions were from Kemika, Zagreb, Croatia, unless otherwise stated. Water for injection (WFI) was from the Croatian Institute of Transfusion Medicine, Zagreb, Croatia.

\subsection{Snake Venoms and Antivenoms}

A pooled sample of $V$. ursinii ssp. venom was obtained by milking more than 10 adult snakes caught at an isolated locality of the southern Velebit, identified by an expert herpetologist and then released. A small amount of venom was also collected from 4 adult $V$. ursinii ssp. snakes kept in captivity for research purposes at Zagreb Zoo Research and Conservation Centre, and designated as $V u$ Cro-c. Two of these (male and female) were captured 6 years ago, and, since then, fed exclusively on mice. Two were however born in captivity and have never been fed on insects. Crude venom of $V$. $a$. ammodytes was collected by milking snakes kept at the Institute of Immunology Inc., Zagreb, Croatia. All V. ursinii ssp. and V.a. ammodytes venom samples were air dried at room temperature and stored in the dark at $+4{ }^{\circ} \mathrm{C}$ until use.

Rabbit serum against the whole $V$. a. ammodytes venom (anti-Vaa) and against $V$. a. ammodytes venom's components: haemorrhagins (anti-H), Atx (anti-Atx) and AtnI 2 (anti-AtnI $\mathrm{I}_{2}$ ) were produced on a small scale according to the in house immunisation scheme [48,49].

\subsection{Animals for In Vivo Assays}

All animal procedures were approved by the Croatian Ministry of Agriculture, Veterinary and Food Safety Directorate (UP/I-322-01/17-01/75, permission no. 525-10/0255-17-6, date 12 December 2017), the Animal Protection Department and the University of Zagreb's Animal Welfare Committee. Animal work was in accordance to Croatian Low on Animal Welfare (2017), which complies strictly with the EC Directive (2010/63/EU) and the ARRIVE guidelines for the Report for in vivo experiments [50]. The approval is based on the positive opinion of the National Ethical Committee (EP 110/2017, date 14 September 2017).

Mice and rats used for in vivo assays were bred at the Institute of Immunology Inc., Croatia. Mice used for the assay of lethal toxicity were of the NIH Ola/Hsd strain. Rats of the Lewis strain were used to assess haemorrhagic activity. Animals were housed under a $12 \mathrm{~h}$ light/dark cycle at a temperature of $23 \pm 3{ }^{\circ} \mathrm{C}$. A standard mouse/rat diet (Mucedola srl, Milano, Italy) and water were supplied ad libitum during the whole period of experiments.

\subsection{Assay of Lethal Toxicity in Mice}

Lethal toxicity, expressed as the median lethal dose $\left(\mathrm{LD}_{50}\right)$, was determined in adult male NIH Ola/Hsd mice according to the method of Theakston and Reid [51] and European Pharmacopeia (Ph.Eur.01/2008:0145). Groups of six animals (18-20 g each) were injected i.v. with $250 \mu \mathrm{L}$ of the 
respective venom solution in saline. Venom doses ranged from 5.25 to $25 \mu \mathrm{g}$ per mouse. Mortality was recorded after $48 \mathrm{~h}$. For each venom sample, the assay was repeated at least twice and up to five times. The median lethal dose was calculated by Spearman-Kärber analysis. The results were expressed as the mean of $n$ determinations \pm standard error (SE).

\subsection{Assay of Lethal Toxicity in Crickets}

The entomotoxic effects of $V$. ursinii ssp. and $V$. a. ammodytes venoms were investigated on crickets (Gryllus assimilis) as described [7]. Crickets (0.50-0.95 g each), in groups of 4, were injected with $5 \mu \mathrm{L}$ of solutions in water for injection (WFI) of the respective venom. Venom doses ranged from 1.56 to $100 \mu \mathrm{g}$ per cricket. An equal volume of WFI was injected into a control group. Mortality was recorded after 48 $\mathrm{h}$. The median lethal dose was calculated by Spearman-Kärber analysis. The results were given as the mean of $n$ determinations \pm SEM.

\subsection{Assay for Assessing Haemorrhagic Activity}

Haemorrhagic activity was estimated according to Theakston and Reid [51], with experimental details as described in [52]. Briefly, Lewis rats (250 g) were shaved on the dorsal skin and injected i.d. with $100 \mu \mathrm{L}$ of the venom solution in saline. Six doses, spanning from 1.28 to $50 \mu \mathrm{g}$, were tested on each animal. The haemorrhagic lesions on the inner surface of the removed skin were observed $24 \mathrm{~h}$ later and their perpendicular diameters measured, from which the average value for each venom dose was calculated. The minimal haemorrhagic dose (MHD) of the venom is defined as the amount of venom ( $\mu \mathrm{g}$ dry mass) which, when injected intradermally, $24 \mathrm{~h}$ later results in a haemorrhagic lesion of $10 \mathrm{~mm}$ in diameter. Results are given as means of $n$ determinations \pm SEM.

\subsection{Immunochemical Assays}

\subsubsection{ELISA Assay}

ELISA assays for detecting haemorrhagin-, Atx- or Atn-like proteins in V. ursinii ssp. venom were performed as described [53]. Briefly, microtiter plates were coated with $100 \mu \mathrm{L} /$ well of the venom solution $(1 \mu \mathrm{g} / \mathrm{mL})$ in $50 \mathrm{mM}$ carbonate buffer, $\mathrm{pH} 9.6$, and left overnight at room temperature (RT). After washing and blocking with $0.5 \%(\mathrm{~m} / \mathrm{v})$ BSA in PBS/T $(0.05 \%(\mathrm{v} / \mathrm{v})$ Tween 20 in PBS) buffer $\left(200 \mu \mathrm{L} /\right.$ well) at $37^{\circ} \mathrm{C}$ for $2 \mathrm{~h}$. The rabbit antisera against whole $V$. a. ammodytes venom (anti-Vaa) or its components (anti-H, anti-Atx or anti-AtnI $)_{2}$ ) were added in 2-fold serial dilutions (100 $\mu \mathrm{L} /$ well) in duplicate and left overnight at RT. In the subsequent steps, incubation with HRP-anti-rabbit IgG (100 $\mu \mathrm{L} /$ well of a 10,000 -fold dilution) at $37^{\circ} \mathrm{C}$ for $2 \mathrm{~h}$ took place, followed by the addition of $100 \mu \mathrm{L} /$ well of OPD solution $\left(0.6 \mathrm{mg} / \mathrm{mL}\right.$ with $0.015 \% \mathrm{H}_{2} \mathrm{O}_{2}(\mathrm{v} / \mathrm{v})$ in citrate-phosphate buffer, $\left.\mathrm{pH} 5.0\right)$. After 30 min incubation in the dark, the enzymatic reaction was stopped with $1 \mathrm{M} \mathrm{H}_{2} \mathrm{SO}_{4}(50 \mu \mathrm{L} /$ well $)$ and the absorbance at $492 \mathrm{~nm}$ measured.

\subsubsection{One-Dimensional SDS-PAGE (1-DE) and Western Blot}

1-DE analysis of $V$. ursinii ssp. and $V$. a. ammodytes venoms was performed on 4-12\% Bis-Tris precast gels with MES as running buffer, under both reducing and non-reducing conditions at $180 \mathrm{~V}$ for $50 \mathrm{~min}$ in an Xcell SureLock Mini-Cell, according to the manufacturer's instructions (Invitrogen, Carlsbad, CA, USA). A total of $40 \mu \mathrm{g}$ of respective venom was applied in each well. Molecular mass standards were from Invitrogen. Protein staining was carried out with CBB R250. For Western blots (WB) following SDS-PAGE analysis, venoms were electro-blotted to the PVDF membrane (GE Healthcare, Buckinghamshire, UK) in an Xcell Sure Lock Mini Cell according to the manufacturer's procedure (Invitrogen, Carlsbad, CA, USA). The blocking was performed with $2 \%(\mathrm{~m} / \mathrm{v}) \mathrm{BSA}$ in PBS/T buffer at $+4{ }^{\circ} \mathrm{C}$ overnight. The blotted membrane was incubated first with anti-Atx serum (diluted 20,000-fold) and then with HRP-anti-rabbit IgG (diluted 10,000-fold) at $37^{\circ} \mathrm{C}$ for $1 \mathrm{~h}$. The Enhanced 
ChemiLuminescence (ECL) plus Western Blotting Detection System was used for detection, according to the manufacturer's instructions (GE Healthcare, Buckinghamshire, UK).

\subsection{Two-Dimensional Gel Electrophoresis (2-DE)}

In the first dimension, isoelectric focusing of $V$. a. ammodytes and $V$. ursinii ssp. venoms was performed in a ZOOM IPG Runner Mini-Cell, using immobilised pH gradient (IPG) strips (7 cm long, non-linear $\mathrm{pH} 3-10)$ previously rehydrated with the protein sample (250 $\mathrm{gg})$, according to the manufacturer's procedure (Invitrogen, Carlsbad, CA, USA). The following voltage protocol was applied: $200 \mathrm{~V}$ for $20 \mathrm{~min}, 450 \mathrm{~V}$ for $15 \mathrm{~min}, 750 \mathrm{~V}$ for $15 \mathrm{~min}$ and $2000 \mathrm{~V}$ for $5 \mathrm{~h}$. The focused IPG strips were first reduced with $20 \mathrm{mM}$ DTT, then alkylated with $125 \mathrm{mM}$ IAA. Cys residues in proteins are namely not stable, which hinders their precise analysis. Reaction of Cys residues with IAA derivatizes them to S-carbamidomethyl-Cys residues, which are, however, stable. Each step was performed for $15 \mathrm{~min}$ at RT. In the second dimension, SDS-PAGE was performed as described under 5.7.2. For spot detection and quantification, the gel image obtained by an Image Scanner using LabScan 5 software was analysed by Image Master 2D Platinum 6.0 software (GE Healthcare, Amersham Biosciences, Amersham, UK). The 2-DE spot intensity was calculated by integrating the optical density over the spot area.

\subsection{Mass Spectrometry (MS) Analysis}

V. ursinii ssp. venom proteins, separated by 1-DE or 2-DE, were excised from the gel and digested with trypsin. The resulting peptides were extracted from the gel and analysed on an ESI-IT mass spectrometer, 1200 series HPLC-Chip-LC/MSD Trap XCT Ultra (Agilent Technologies, Waldbronn, Germany), as described in [54]. Prior to MS analysis, peptides were purified on self-prepared Stage-Tips. Proteins were identified using licensed software MASCOT version 2.1 (Matrix Science, London, UK), searching the "Snakes" (taxid 8750; 159,187 entries) protein database extracted from the non-redundant NCBI (National Centre for Biotechnology Information) protein databank in December 2017 and supplemented with the $V . a$. ammodytes venom gland cDNA transcripts library [55]. The following search parameters were used: parent ion error tolerance of 1.2 Da, fragment error tolerance of $0.60 \mathrm{Da}$, maximum of 2 missed cleavages allowed, peptide charges +2 and +3 , methionine oxidation as variable and carboxamidomethyl cysteine as fixed modification, and an automatic decoy database search. The results were validated using Scaffold software (version 2, Proteome Software, Inc., Portland, OR, USA) with the following parameters: protein threshold of $95 \%$, minimum one peptide per protein and a peptide threshold of $90 \%$. The estimated Prophet false discovery rate was $0.2 \%$ for proteins and $5.6 \%$ for peptides. Additional peptide matches to identified proteins were obtained by performing an error-tolerant Mascot search and manual validation of the obtained results.

Supplementary Materials: The following are available online at http://www.mdpi.com/2072-6651/12/3/187/s1, Table S1: Identification of the structures of the Croatian V. ursinii ssp. venom proteins. Table S2: Identification of proteins with higher abundance in the venom of the Croatian V. ursinii ssp. snakes living in captivity (VuCro-c) than in the venom of those living in the wild (VuCro).

Author Contributions: Conceptualization, M.L.B., A.L., B.H., I.K.; methodology, M.L.B., A.L., B.H., I.K.; formal analysis, M.L.B., A.L., M.B., D.S., T.K., B.H., I.K.; investigation, M.L.B., A.L., M.B., D.S., T.K.; writing-original draft preparation, M.L.B., A.L., B.H., I.K.; writing-review and editing, M.L.B., A.L., M.B., D.S., T.K., B.H., I.K.; supervision, B.H., I.K.; project administration, B.H., I.K.; funding acquisition, B.H., I.K. All authors have read and agreed to the published version of the manuscript.

Funding: This research was funded by the Croatian-Slovenian collaborative project (BI-HR/16-17-002 to I.K. and B.H.), by Slovenian Research Agency (grant P1-0207 to I.K.) and by Croatian Science Foundation (grant IP-2014-09-4915 to B.H.).

Acknowledgments: The authors thank D. Jelić (Croatia, Hyla) for providing venom samples from the protected area of V. ursinii ssp. in Croatia. We are also grateful to Ingeborg Bata (Croatia, ZOO Zagreb) and Siniša Vajdić (Croatia, Faculty of Science, University of Zagreb) for providing crickets. Our sincere thanks go to Nikola Tvrtković who helped us to handle crickets and for his information on V. ursinii behaviour in their natural habitat, and to Roger H. Pain for critical reading of the manuscript. 
Conflicts of Interest: The authors declare no conflict of interest. The funders had no role in the design of the study; in the collection, analyses, or interpretation of data; in the writing of the manuscript, or in the decision to publish the results.

\section{References}

1. Uetz, P.; Freed, P.; Hošek, J. The Reptile Database. Available online: http://www.reptile-database.org/ (accessed on 2 December 2019).

2. Mizsei, E.; Jablonski, D.; Roussos, S.A.; Dimaki, M.; Ioannidis, Y.; Nilson, G.; Nagy, Z.T. Nuclear markers support the mitochondrial phylogeny of Vipera ursinii-renardi complex (Squamata: Viperidae) and species status for the Greek meadow viper. Zootaxa 2017, 4227. [CrossRef] [PubMed]

3. Council of Europe, Convention on the Conservation of European Wildlife and Natural Habitats: Action Plan for the Conservation of the Meadow Viper (Vipera ursinii) in Europe, T-PVS/Inf, 20051 Revised. Available online: https://rm.coe.int/16807462b0 (accessed on 2 December 2019).

4. Ferchaud, A.L.; Ursenbacher, S.; Cheylan, M.; Luiselli, L.; Jelić, D.; Halpern, B.; Major, Á.; Kotenko, T.; Keyan, N.; Behrooz, R.; et al. Phylogeography of the Vipera ursinii complex (Viperidae): Mitochondrial markers reveal an east-west disjunction in the Palaearctic region. J. Biogeogr. 2012, 39, 1836-1847. [CrossRef]

5. Jelić, D.; Ajtić, R.; Sterijovski, B.; Crnobrnia-Isailović, J.; Lelo, S.; Tomović, L. Distribution of the genus Vipera in the western and central Balkans (Squamata: Serpentes: Viperidae). Herpetozoa 2013, 25, 109-132.

6. Jelić, D.; Ajtić, R.; Sterijovski, B.; Crnobrnja-Isailović, J.; Lelo, S.; Tomović, L. Legal status and assessment of conservation threats to vipers (Reptilia: Squamata: Viperidae) of the Western and Central Balkans. Herpetol. Conserv. Biol. 2013, 8, 764-770.

7. Starkov, V.G.; Osipov, A.V.; Utkin, Y.N. Toxicity of venoms from vipers of Pelias group to crickets Gryllus assimilis and its relation to snake entomophagy. Toxicon 2007, 49, 995-1001. [CrossRef]

8. Krescák, L.; Zacher, G.; Malina, Z. Clinical picture of envenoming with the Meadow Viper (Vipera (Acridophaga) ursinii). Clin. Toxicol. 2011, 49, 13-20.

9. Gvoždík, V.; Jandzik, D.; Cordos, B.; Rehák, I.; Kotlík, P. A mitochondrial DNA phylogeny of the endangered vipers of the Vipera ursinii complex. Mol. Phylogenet. Evol. 2012, 62, 1019-1024. [CrossRef]

10. Ferchaud, A.-L.; Lyet, A.; Cheylan, M.; Arnal, V.; Baron, J.-P.; Montgelard, C.; Ursenbacher, S. High genetic differentiation among French populations of the Orsini's viper (Vipera ursinii ursinii) based on mitochondrial and microsatellite data: Implications for conservation management. J. Hered. 2011, 102, 67-78. [CrossRef]

11. Mebs, D.; Langelüddeke, T. European viper venoms: Haemorrhagic and myotoxic activities. Toxicon 1992, 30, 1303-1306. [CrossRef]

12. Jan, V.M.; Guillemin, I.; Robbe-Vincent, A.; Choumet, V. Phospholipase $\mathrm{A}_{2}$ diversity and polymorphism in European viper venoms: Paradoxical molecular evolution in Viperinae. Toxicon 2007, 50, 1140-1161. [CrossRef]

13. Halassy, B.; Brgles, M.; Habjanec, L.; Balija, M.L.; Kurtović, T.; Marchetti-Deschmann, M.; Križaj, I.; Allmaier, G. Intraspecies variability in Vipera ammodytes ammodytes venom related to its toxicity and immunogenic potential. Comp. Biochem. Physiol. C Toxicol. Pharmacol. 2011, 153, 223-230. [CrossRef] [PubMed]

14. Halassy, B.; Habjanec, L.; Balija, M.L.; Kurtović, T.; Brgles, M.; Križaj, I. Ammodytoxin content of Vipera ammodytes ammodytes venom as a prognostic factor for venom immunogenicity. Comp. Biochem. Physiol. C Toxicol. Pharmacol. 2010, 151, 455-460. [CrossRef] [PubMed]

15. Leonardi, A.; Sajevic, T.; Pungerčar, J.; Križaj, I. Comprehensive study of the proteome and transcriptome of the venom of the most venomous european viper: Discovery of a new subclass of ancestral snake venom metalloproteinase precursor-derived proteins. J. Proteome Res. 2019, 18, 2287-2309. [CrossRef] [PubMed]

16. Barlow, A.; Pook, C.E.; Harrison, R.A.; Wüster, W. Coevolution of diet and prey-specific venom activity supports the role of selection in snake venom evolution. Proc. Biol. Sci. 2009, 276, 2443-2449. [CrossRef] [PubMed]

17. Richards, D.P.; Barlow, A.; Wüster, W. Venom lethality and diet: Differential responses of natural prey and model organisms to the venom of the saw-scaled vipers (Echis). Toxicon 2012, 59, 110-116. [CrossRef] [PubMed]

18. Mackessy, S.P.; Sixberry, N.M.; Heyborne, W.H.; Fritts, T. Venom of the brown treesnake, Boiga irregularis: Ontogenetic shifts and taxa-specific toxicity. Toxicon 2006, 47, 537-548. [CrossRef] 
19. Calvete, J.J.; Sanz, L.; Angulo, Y.; Lomonte, B.; Gutiérrez, J.M. Venoms, venomics, antivenomics. FEBS Lett. 2009, 583, 1736-1743. [CrossRef]

20. Tasoulis, T.; Isbister, G.K. A review and database of snake venom proteomes. Toxins 2017, 9, 290. [CrossRef]

21. Latinović, Z.; Leonardi, A.; Šribar, J.; Sajevic, T.; Žužek, M.C.; Frangež, R.; Halassy, B.; Trampuš-Bakija, A.; Pungerčar, J.; Križaj, I.; et al. Venomics of Vipera berus berus to explain differences in pathology elicited by Vipera ammodytes ammodytes envenomation: Therapeutic implications. J. Proteom. 2016, 146, 34-47. [CrossRef]

22. Sajevic, T.; Leonardi, A.; Križaj, I. Haemostatically active proteins in snake venoms. Toxicon 2011, 57, 627-645. [CrossRef]

23. Chellapandi, P. Structural, functional and therapeutic aspects of snake venom metalloproteinases. Mini Rev. Org. Chem. 2014, 11, 28-44. [CrossRef]

24. Gutiérrez, J.M.; Escalante, T.; Rucavado, A.; Herrera, C. Hemorrhage caused by snake venom metalloproteinases: A journey of discovery and understanding. Toxins 2016, 8, 93. [CrossRef] [PubMed]

25. Sajevic, T.; Leonardi, A.; Kovačič, L.; Lang-Balija, M.; Kurtović, T.; Pungerčar, J.; Halassy, B.; Trampuš-Bakija, A.; Križaj, I. VaH3, one of the principal hemorrhagins in Vipera ammodytes ammodytes venom, is a homodimeric P-IIIc metalloproteinase. Biochimie 2013, 95, 1158-1170. [CrossRef] [PubMed]

26. Slagboom, J.; Kool, J.; Harrison, R.A.; Casewell, N.R. Haemotoxic snake venoms: Their functional activity, impact on snakebite victims and pharmaceutical promise. Br. J. Haematol. 2017, 177, 947-959. [CrossRef] [PubMed]

27. Leonardi, A.; Fox, J.W.; Trampuš-Bakija, A.; Križaj, I. Two coagulation factor X activators from Vipera $a$. ammodytes venom with potential to treat patients with dysfunctional factors IXa or VIIa. Toxicon 2008, 52, 628-637. [CrossRef] [PubMed]

28. Takeya, H.; Nishida, S.; Miyata, T.; Kawada, S.; Saisaka, Y.; Morita, T.; Iwanaga, S. Coagulation factor X activating enzyme from Russell's viper venom (RVV-X). A novel metalloproteinase with disintegrin (platelet aggregation inhibitor)-like and C-type lectin-like domains. J. Biol. Chem. 1992, 267, 14109-14117.

29. Tokunaga, F.; Nagasawa, K.; Tamura, S.; Miyata, T.; Iwanaga, S.; Kisiel, W. The factor V-activating enzyme (RVV-V) from Russell's viper venom. Identification of isoproteins RVV-V alpha, $-\mathrm{V}$ beta, and -V gamma and their complete amino acid sequences. J. Biol. Chem. 1988, 263, 17471-17481.

30. Segers, K.; Rosing, J.; Nicolaes, G.A.F. Structural models of the snake venom factor V activators from Daboia russelli and Daboia lebetina. Proteins 2006, 64, 968-984. [CrossRef]

31. Latinović, Z.; Leonardi, A.; Kovačič, L.; Koh, C.; Šribar, J.; Bakija, A.; Venkateswarlu, D.; Kini, R.; Križaj, I. The first intrinsic tenase complex inhibitor with serine protease structure offers a new perspective in anticoagulant therapy. Thromb. Haemost. 2018, 118, 1713-1728. [CrossRef]

32. de Queiroz, M.R.; de Sousa, B.B.; da Cunha Pereira, D.F.; Mamede, C.C.N.; Matias, M.S.; de Morais, N.C.G.; de Oliveira Costa, J.; de Oliveira, F. The role of platelets in hemostasis and the effects of snake venom toxins on platelet function. Toxicon 2017, 133, 33-47. [CrossRef]

33. Komori, Y.; Nikai, T.; Sugihara, H. Comparative study of three phospholipase $\mathrm{A}_{2} \mathrm{~S}$ from the venom of Vipera aspis. Comp. Biochem. Physiol. B 1990, 97, 507-514. [CrossRef]

34. Tsai, I.-H.; Wang, Y.-M.; Cheng, A.C.; Starkov, V.; Osipov, A.; Nikitin, I.; Makarova, Y.; Ziganshin, R.; Utkin, Y. cDNA cloning, structural, and functional analyses of venom phospholipases $\mathrm{A}_{2}$ and a Kunitz-type protease inhibitor from steppe viper Vipera ursinii renardi. Toxicon 2011, 57, 332-341. [CrossRef] [PubMed]

35. Križaj, I. Ammodytoxin: A window into understanding presynaptic toxicity of secreted phospholipases $\mathrm{A}_{2}$ and more. Toxicon 2011, 58, 219-229. [CrossRef] [PubMed]

36. Matsunaga, Y.; Yamazaki, Y.; Hyodo, F.; Sugiyama, Y.; Nozaki, M.; Morita, T. Structural divergence of cysteine-rich secretory proteins in snake venoms. J. Biochem. 2009, 145, 365-375. [CrossRef] [PubMed]

37. Lodovicho, M.E.; Costa, T.R.; Bernardes, C.P.; Menaldo, D.L.; Zoccal, K.F.; Carone, S.E.; Rosa, J.C.; Pucca, M.B.; Cerni, F.A.; Arantes, E.C.; et al. Investigating possible biological targets of Bj-CRP, the first cysteine-rich secretory protein (CRISP) isolated from Bothrops jararaca snake venom. Toxicol. Lett. 2016, 265, 156-169. [CrossRef]

38. Wang, Y.L.; Kuo, J.H.; Lee, S.C.; Liu, J.S.; Hsieh, Y.C.; Shih, Y.T.; Chen, C.J.; Chiu, J.J.; Wu, W.G. Cobra CRISP functions as an inflammatory modulator via a novel $\mathrm{Zn}^{2+}$ - and heparan sulfate-dependent transcriptional regulation of endothelial cell adhesion molecules. J. Biol. Chem. 2010, 285, 37872-37883. [CrossRef] 
39. Adade, C.M.; Carvalho, A.L.O.; Tomaz, M.A.; Costa, T.F.R.; Godinho, J.L.; Melo, P.A.; Lima, A.P.C.A.; Rodrigues, J.C.F.; Zingali, R.B.; Souto-Padrón, T.; et al. Crovirin, a snake venom cysteine-rich secretory protein (CRISP) with promising activity against Trypanosomes and Leishmania. PLoS Negl. Trop. Dis. 2014, 8, e3252. [CrossRef]

40. Lecht, S.; Chiaverelli, R.A.; Gerstenhaber, J.; Calvete, J.J.; Lazarovici, P.; Casewell, N.R.; Harrison, R.; Lelkes, P.I.; Marcinkiewicz, C. Anti-angiogenic activities of snake venom CRISP isolated from Echis carinatus sochureki. Biochim. Biophys. Acta 2015, 1850, 1169-1179. [CrossRef]

41. Trummal, K.; Tõnismägi, K.; Paalme, V.; Järvekülg, L.; Siigur, J.; Siigur, E. Molecular diversity of snake venom nerve growth factors. Toxicon 2011, 58, 363-368. [CrossRef]

42. Ritonja, A.; Turk, V.; Gubenšek, F. Serine proteinase inhibitors from Vipera ammodytes venom. Isolation and kinetic studies. Eur. J. Biochem. 1983, 133, 427-432. [CrossRef]

43. Thakur, R.; Mukherjee, A.K. Pathophysiological significance and therapeutic applications of snake venom protease inhibitors. Toxicon 2017, 131, 37-47. [CrossRef] [PubMed]

44. Brgles, M.; Kurtović, T.; Kovačič, L.; Križaj, I.; Barut, M.; Balija, M.L.; Allmaier, G.; Marchetti-Deschmann, M.; Halassy, B. Identification of proteins interacting with ammodytoxins in Vipera ammodytes ammodytes venom by immuno-affinity chromatography. Anal. Bioanal. Chem. 2014, 406, 293-304. [CrossRef] [PubMed]

45. Gibbs, H.L.; Sanz, L.; Chiucchi, J.E.; Farrell, T.M.; Calvete, J.J. Proteomic analysis of ontogenetic and diet-related changes in venom composition of juvenile and adult Dusky Pigmy rattlesnakes (Sistrurus miliarius barbouri). J. Proteom. 2011, 74, 2169-2179. [CrossRef] [PubMed]

46. Ogawa, T.; Nakashima, K.; Nobuhisa, I.; Deshimaru, M.; Shimohigashi, Y.; Fukumaki, Y.; Sakaki, Y.; Hattori, S.; Ohno, M. Accelerated evolution of snake venom phospholipase $\mathrm{A}_{2}$ isozymes for acquisition of diverse physiological functions. Toxicon 1996, 34, 1229-1236. [CrossRef]

47. Aird, S.D.; Aggarwal, S.; Villar-Briones, A.; Tin, M.M.-Y.; Terada, K.; Mikheyev, A.S. Snake venoms are integrated systems, but abundant venom proteins evolve more rapidly. BMC Genom. 2015, 16, 647. [CrossRef]

48. Halassy, B.; Habjanec, L.; Brgles, M.; Balija, M.L.; Leonardi, A.; Kovačič, L.; Prijatelj, P.; Tomašić, J.; Križaj, I. The role of antibodies specific for toxic sPLA ${ }_{2} \mathrm{~s}$ and haemorrhagins in neutralizing potential of antisera raised against Vipera ammodytes ammodytes venom. Comp. Biochem. Physiol. C Toxicol. Pharmacol. 2008, 148, 178-183. [CrossRef]

49. Kurtović, T.; Leonardi, A.; Lang Balija, M.; Brgles, M.; Habjanec, L.; Križaj, I.; Halassy, B. The standard mouse assay of anti-venom quality does not measure antibodies neutralising the haemorrhagic activity of Vipera ammodytes venom. Toxicon 2012, 59, 709-717. [CrossRef]

50. Kilkenny, C.; Browne, W.J.; Cuthill, I.C.; Emerson, M.; Altman, D.G. Improving bioscience research reporting: The ARRIVE guidelines for reporting animal research. PLoS Biol. 2010, 8, e1000412. [CrossRef]

51. Theakston, R.D.G.; Reid, H.A. Development of simple standard assay procedures for the characterization of snake venoms. Bull. World Health Organ. 1983, 61, 949-956.

52. Lang Balija, M.; Vrdoljak, A.; Habjanec, L.; Dojnović, B.; Halassy, B.; Vranešić, B.; Tomašić, J. The variability of Vipera ammodytes ammodytes venoms from Croatia-Biochemical properties and biological activity. Comp. Biochem. Physiol. C Toxicol. Pharmacol. 2005, 140, 257-263. [CrossRef]

53. Kurtović, T.; Lang Balija, M.; Ayvazyan, N.; Halassy, B. Paraspecificity of Vipera a. ammodytes-specific antivenom towards Montivipera raddei and Macrovipera lebetina obtusa venoms. Toxicon 2014, 78, 103-112. [CrossRef] [PubMed]

54. Leonardi, A.; Biass, D.; Kordiš, D.; Stöcklin, R.; Favreau, P.; Križaj, I. Conus consors snail venom proteomics proposes functions, pathways, and novel families involved in its venomic system. J. Proteome Res. 2012, 11, 5046-5058. [CrossRef] [PubMed]

55. Leonardi, A.; Sajevic, T.; Kovačič, L.; Pungerčar, J.; Lang Balija, M.; Halassy, B.; Trampuš Bakija, A.; Križaj, I. Hemorrhagin VaH4, a covalent heterodimeric P-III metalloproteinase from Vipera ammodytes ammodytes with a potential antitumour activity. Toxicon 2014, 77, 141-155. [CrossRef] [PubMed]

(C) 2020 by the authors. Licensee MDPI, Basel, Switzerland. This article is an open access article distributed under the terms and conditions of the Creative Commons Attribution (CC BY) license (http://creativecommons.org/licenses/by/4.0/). 